\title{
The Iconomics of New Developmentalism
}

\author{
A “iconomia” do Novo Desenvolvimentismo
}

GILSON SCHWARTZ*,**;***

RESUMO: As revisões atuais do novo desenvolvimentismo, na perspectiva da Economia Política, apresentam sua novidade em termos de mudança de paradigma, análise comparativa e reconstrução histórico-ideológica. Este artigo revisa essas abordagens complementares, a fim de iniciar uma revisão crítica alternativa da nova agenda desenvolvimentista, levando em consideração o surgimento de mais uma teoria pós-estruturalista, a saber, "iconômica". O fundamento da perspectiva iconômica é um método semiótico-sociológico inspirado nos trabalhos de G.L.S. Shackle, Bernard Stiegler e Joseph Schumpeter. As teorias de valor, resiliência e perturbação baseadas no conhecimento são os principais conceitos que emergem dessa revisão teórico-metodológica “iconômica” que pode levar a proposições no campo da política econômica, teoria do crescimento e filosofia política que ampliam o legado estruturalista-desenvolvimentista. Propomos uma abordagem para a identificação do desenvolvimentismo que apoie uma abordagem crítica da economia política das visões de escolha ultraliberal, positivista e racional.

PALAVRAS-CHAVE: Desenvolvimentismo; iconomia; valor; método; economia política.

ABSTRACT: Current reviews of new developmentalism from a Political Economy perspective present its novelty in terms of a paradigm shift, a comparative analysis and a historical-ideological reconstruction. This paper reviews these complementary approaches so as to initiate an alternative, critical review of the new developmentalist agenda taking into consideration the emergence of yet another post-structuralist theory, namely, "iconomics". The grounding of the iconomic perspective is a semiotic-sociological method inspired by the works of G.L.S. Shackle, Bernard Stiegler and Joseph Schumpeter. Knowledge-based theories of value, resilience and disruption are the key concepts that emerge out of this "iconomic" theoretical-methodological review which may lead to propositions in the field of economic policy,

\footnotetext{
* Professor Livre-Docente, Departamento de Cinema, Rádio e TV da Escola de Comunicações e Artes (CTR-ECA) e Programa de Pós-Graduação Interdisciplinar Humanidades, Direitos e Outras Legitimidades da Faculdade de Filosofia, Letras e Ciências Humanas (FFLCH) da Universidade de São Paulo (USP), São Paulo/SP, Brasil. E-mail: schwartz@usp.br ORCID: https://orcid.org/0000-0002-0198-3489.

** Professor Visitante do Departamento de Humanidades Digitais do King's College de Londres.

*** Paper presented to the 4th Workshop on New Developmentalism of Fundação Getulio Vargas “Theory and Policy for Developing Countries”, São Paulo, $25-26$ July 2019. Submitted: 25/July/2019; Approved: 1/August/2019..
} 
growth theory and political philosophy that extend the structuralist-developmentalist legacy. We propose an approach to the identification of developmentalism that supports a critical approach to the political economy of the ultraliberal, positivist and rational choice visions. KEYWORDS: Developmentalism; iconomics; value; methodology; political economy. JEL Classification: B; 0.

"Those books, therefore, called Elements, Principles, or Systems of Political Economy, which do not embrace and fully develop, as not one of them does, the whole influence of knowledge on productive power, and do not explain the natural laws which regulate the progress of society in knowledge, are and must, as treatises on Political Economy, be essentially incomplete."

Thomas Hodgskin, Popular Political Economy, Four Lectures Delivered at the London Mechanics'Institution, London, p. 97 (1827)

"The ideas of economists and political philosophers, both when they are right acnd when they are wrong, are more powerful than is commonly understood. Indeed, the world is ruled by little else. Practical men, who believe themselves to be quite exempt from any intellectual influence, are usually the slaves of some defunct economist. Madmen in authority, who hear voices in the air, are distilling their frenzy from some academic scribbler of a few years back. I am sure that the power of vested interests is vastly exaggerated compared with the gradual encroachment of ideas."

John Maynard Keynes, The General Theory of Employment, Interest and Money, chapter 24, p. 383 (1935)

"Furtado plays with the idea of a religious missionary when he tells Jorge Ahumada that 'we, unknowingly, constitute an Order, of those who preach for the faith in Development'. He laughed and replied: even worse, as Jesuits are now competing with us and I have no clue as to what will come out of this."

Celso Furtado, Obra Autobiográfica: A Fantasia Organizada, A Fantasia Desfeita, Os Ares do Mundo, São Paulo, Companhia das Letras, 2014, citato por Elisa Klüger, Meritocracia de Laços, Tese de Doutoramento, FFLCH-USP, 2017.

\section{DISRUPTION OF BOURGEOIS UTOPIAS}

The history of Brazilian economic thought is a field in the making, the political economy perspective requires a paradigm shift, intensive comparative analysis and a historical-ideological reconstruction that is interdisciplinary.

The emergence of a "new developmentalist" perspective inspires the perception of what has been defined by Pierre Bourdieu as a "field", a knowledge produced by the habitus conditioned by different forms of capital, power and belief. Bresser- 
Pereira invites us to protest and engage in a sort of activism that reminds us all of his youth in the 1950s.

From an epistemic perspective, new developmentalism must perform a final, "iconomic" turn to actually perform as a paradigm shift based on comparative analysis and a faithful, reasonable and arguable historical-ideological reconstruction.

This epistemic turn is in the making for at least 200 years! Back in 1827, Hodgskin warned us about the difficulty among "political economists" to effectively integrate knowledge in their treatises. Keynes, about 100 years later, would also insist on the importance of ideas in the progress of economies and economic policies (even more relevant than vested interests). Celso Furtado also insisted on the cultural and almost religious role of economic ideas.

However, many a "developmentalist" insists on a dialogue with defunct paradigms, as if there would be a scientific, analytic perspective to be erected on the ruins of classical and neoclassical models of reality and policy-making.

In other words, new developmentalism or even "developmentalism" as such must become an icon. An icon of economic science in all its multifarious expressions - an icon as strong and faithful as "equilibrium" in the neoclassical paradigm or "accumulation" in the Marxist optics.

Pierre Bourdieu is a helpful research mentor in the investigation of "developmentalism" as an icon, a piece of theoretical transcendence rooted in the existential, historical and ideological quest for the foundations of life, value and understanding. It is not just a matter of doing a sociology of economics or an anthropology of economic science. Since at least the 19th century the epistemic dimension of economics (not only economic analysis) has been again and again stressed by heterodox or "popular" economists. Even Marx had to deal with the fact that a "general intellect" was the underlying factor conducive to industrial capitalism.

It is noteworthy and actually timely to stress the "space" occupied by BresserPereira in Klüger's Bourdieusian account (actually still in the field of a sociology of economic professionals). What matters in our perspective is that Bresser-Pereira is clearly associated by Klüger, as was Celso Furtado, to Developmentalism as an article of faith, in the Schumpeterian sense of a "vision" - a preliminary and overdetermining factor that prevails as a Kantian condition for "analysis".

Furtado and Bresser-Pereira are brothers in arms: they envisage history as an angel depicted by Paul Klee's angel (as interpreted by Walter Benjamin): progress is not part of the Law, there is no way to fly forward to the future but to turn the face to the accumulation of destruction, disruption and death produced by the history of the past generations. This critical and dystopian view of History should also be part of a history of economic ideologies.

The purpose - faith in development - is supported by an agent of change, a leading, protagonistic subject, a collective intelligence associated to the Nation, Brazil or any other collectivity in the Periphery of Space and Time in the "March of History" led by the dominant countries and their ruling classes.

Klüger (2017) traces the networks and power flows among the developmentalists since the industrial emergence of São Paulo as the "locomotive" of industrial 
development in Brazil, in the early 1930s. There is a clear conflict among Rio de Janeiro (heir to the Luso-Brazilian Empire) and São Paulo (birthplace of a vigorous industrialism). The history of the Fundação Getulio Vargas is a testimony to this astonishing work of individuals and a collective intelligence, a generational and demographic consciousness-of-themselves, a period in Brazilian history that was expressed from the 1950s onwards as a "new bossa" (Bossa Nova) in Rio de Janeiro, but actually unfolding as tensions among the legacy of colonial elites and the emerging industrial bourgeoisie. As an expression of democracy and a result of the U.S. progressive agendas and policies, generous funding and democratic commitment.

\section{ALTERNATIVE, CRITICAL REVIEW OF THE NEW DEVELOPMENTALIST AGENDA}

The numerous connections among different developmentalist "families" in the US, in Latin America, in Europe or in Asia (João Paulo dos Reis Velloso was reknowned for his references to the Asian "models") and the shared refusal of the neoclassical "equilibrium" models are evidence of a shared field of knowledge that only partially borders Neoclassical "equilibrium" parameters or Marxist "accumulation" issues and crises.

The identification of this knowledge field matches what we could translate as the principle of iconomics, that is, the conscious choice of a fundamental issue which promotes a meaningful perspective for a theory of value (and therefore of prices, profits and other incomes). Development is an icon before aspiring to become a theory.

In order to be meaningful, a theory of value must make sense not only in material terms, but in terms of the degree of consciousness that economic, political and cultural actors have of their role as representations of the very spaces, time horizons and projects held by their social and symbolic capitals.

In short, there must be "faith" in the economic field, faith in the effectiveness of the social, economic, cultural, symbolic and even religious capitals that organize the desires of any given society. There must be a corresponding "Zeitgeist", an "époché" as Bernard Stiegler has stressed over the years, calling attention to the exhaustion of "époché" in the age of hypermaterialism and psychopowered digital engines that stress consumerism as the misleading key to economic progress and political freedom.

From an iconomic perspective, however, the collective faith in a source of value can change as we move through sequential images of the future, fabricated by the development process itself and legitimized by the academic institutions and policy research agencies.

Shackle was probably the only economist to stress the importance of such "figments". "What the decision-maker wants is access to hope", he said. However, figments dissolve in the air.

The iconomic approach may serve us even further, as a preludium to a semi- 
otic-sociological method that deciphers the ultimate sustainability and perenity of the developmentalist paradigm as an article of faith.

In order to pass this "test" of iconicity, developmentalism must perform as language/narrative, as a sufficiently resilient concept/ideology (subject to hysteresis and resilience) and, last but not least, be instrumental in the proposition of innovative economic policies, growth theories and a political philosophy that goes beyond the historically-constrained, exhausted clichés of the structuralist-developmentalist legacy.

From that perspective, new developmentalism could be described as a poststructuralist development theory founded on symbolic resilience.

\section{IDENTIFICATION OF THE NEW DEVELOPMENTALISM FIELD IN ECONOMIC POLICY}

Since there is already a structuralist and a developmentalist macroeconomic theory (essays as well as textbooks), new developmentalism leads to innovations in economic policy as a field of knowledge and practice.

The emphasis on policy malfunctions with clear historical examples (positive or negative) is essential to the emergence and progression of developmentalism as a new field in economic policy. This has been the case since Gershenkron and Rostow, Furtado and Prebisch and continues to be so in the critical insistence of Bresser-Pereira on the perils of the "Dutch Disease".

The next step in order to become part of an iconomic paradigm is for developmentalism to further its perspective on the new frontiers of digital capitalism in knowledge societies, updating the developmentalist state in order to adequately integrate the information and communication value chains as well as their impact on the materiality of costs and revenues into the progressive, emancipatory horizon.

This requires a critical review of the role of knowledge in economic processes, not only scientific knowledge as appropriated in production chains but the very circulation of ideas and mentalities as stressed by John Maynard Keynes.

It must also be stressed that Marx and all variants of Marxism have also missed the point, supposedly in the name of a purely materialist dialetics. The works of Bernard Stiegler have stressed this point while insisting that only by acknowledging the impacts of digital infrastructures on value chains it will be possible to overcome the ultraliberal credo.

The Hegelian and 'idealist' definition of “understanding” was inverted by Marx when he proposed that it is first and foremost a matter of focusing on the "means of production": such is his "materialism". But according to Stiegler, in so dismissing idealism Marx lost sight of the question of ideality, that is, idealization as that which is at work in all investment and in all knowledge of the object of desire (Stiegler, 2015).

According to the French philosopher, Marx (like Althusser after him) commits a fundamental error in assuming that the way the proletariat can escape their con- 
dition is by becoming conscious of their proletarianized situation, rather than through the "elaboration of a new kind of knowledge". In other words, we need not a "Marxist" (or for that matter, a "developmentalist") science, but a new relation of economics to technics which may lead not to a "post-industrial" age, but to a new industrial age where the knowledge production chains are socially redesigned and politically regulated. New form of memory and hope must emerge. Industrial development depends on software, hardware, data, netware, web, metadata, and so on - these have now become the primary economic element according to the French philosopher Bernard Stiegler.

The twenty-first century begins by establishing a revolutionary situation, for two reasons:

- on the one hand, a mutation of industrial material, produced by an industrial world now dominated by the digitalization of industry (by the digital tertiary industry, firstly as hardware and software, then as dataware and metadata ware), resulting in a systemic industrial mutation both by accelerating the obsolescence of the consumerist system founded on centralist organizations, and by opening new, undetermined possibilities in the field of machines, which amount to new possibilities of psychic and collective utopias beyond the disruption caused by financialization;

- on the other hand, the 'technicians' of 'language machines' have been engaged in a revolutionary struggle, a struggle concerned with the production and sharing of knowledge, with a new industrial organization of work, and with intellectual property, and the goal of this struggle has been to constitute an industrial organization founded on a total review of class relations and the role of the State.

We, developmentalists, should be aware that development is also and foremost a mental proclivity - there is a faith in the mentality of development (animal spirits) that must face the parasite status of financialization spirits.

In other words, in order to "develop/mentalism" to make progress, the "therapeutic specificities" of the new epistemic (digital) reality must be brought to the forefront of economic theory and policies. As stressed by Stiegler, the new industrial policy sphere consists not only in industrial machinery as such, but also and above all "the apparatus of digital cultural and cognitive technology that typifies the 'technical reproducibility' of the twenty-first century".

Why have progressives and the left been so late in acknowledging this reality? Why are we still fighting the neoliberal paradigm as if development could fit the macroeconomic language of an ideological macroeconomics that ignores the role of knowledge, innovation and Schumpeterian disruption? Why are we still dealing with "class", "State" and "progress" in terms that have been dissolved by the digital transformation? Parties and movements are "nearly wholly ignorant of these developments, and for this reason they can rightly be referred to as 'progressive' only among inverted commas", insists Stiegler.

As a matter of fact, "the 'progressive' parties and movements, in the twentieth 
century, ultimately made common cause with consumerism", and the Brazilian experience with the Workers Party is just another example of this epistemic mistake. This is yet another reason for the demise of leftist populism as exemplified by both the PSDB and PT governments in Brazil. The problem with workers and the middle class is not one of declining purchasing power, but rather of a "loss of knowledge".

These issues are now emerging as such, and they should lead to "the abandonment of the discourse that defends purchasing power, in favour of the goal of developing a purchasing knowledge, founded on a new producing knowledge and a new conceiving and designing knowledge in the age of digital grammatization and of the contributory economy that it makes possible" (Stiegler).

The emergence of a new developmentalism depends on the proper understanding of the new reticular reorganization of knowledge rather than a tactical alliance with the hyper-financialized consumerism, otherwise no reconstituting of the horizon of belief will be possible.

There must be a massive investment in the new industrial model that is emerging with digitalization, this will lead to new public industrial policies as well as an urge to rethink all other policies (educational, fiscal, familial and intergenerational, that is, social policies, health policies, regional planning policies, and so on) according to this imperative, which alone will enable humanity to regain confidence and avoid a new global military war.

\section{REFERENCES}

Klüger, E., (2017), Meritocracia de Laços: Gênese e Reconfigurações do espaço dos economistas no Brasil, Tese de Doutoramento, Programa de Pós-Graduação em Sociologia da Faculdade de Filosofia, Letras e Ciências Humanas (FFLCH), Universidade de São Paulo.

Stiegler, B., (2015), States of Schock, Stupidity and Knowledge in the Twenty-First Century. Cambridge, UK: Polity Press.

Schwartz, G., (2019), Iconomia, Introdução à Crítica Digital da Economia Industrial e Financeira. Salvador: Editora da Universidade Federal da Bahia. 